\title{
Sperm DNA Fragmentation as a Factor of Male Low Reproductive Function in IVF Practice
}

\author{
Ievgeniia Zhylkova ${ }^{1}$, Olexandr Feskov ${ }^{1}$, Iryna Feskova ${ }^{1}$, Olena Fedota ${ }^{2} \&$ Vladyslav Feskov $^{1}$ \\ ${ }^{1}$ Centre of Human Reproduction "Clinic of Professor Feskov A. M.”, Kharkov, Ukraine \\ ${ }^{2}$ Kharkov National University named after V. N. Karazin, Kharkov, Ukraine \\ Correspondence: Ievgeniia Zhylkova, Centre of Human Reproduction "Clinic of Professor Feskov A. M.”, 61098 \\ Kharkov, Yelizarova Str. 15, Ukraine. Tel: 38-066-765-1055. E-mail: zhilkova@feskov.com.ua
}

Received: August 17, 2013 Accepted: October 15, 2013 Online Published: December 20, 2013

doi:10.5539/ijb.v6n1p75

URL: http://dx.doi.org/10.5539/ijb.v6n1p75

\begin{abstract}
The correlation between semen DNA fragmentation level and the male age was investigated. The dependence for the blastocyst formation rates on the sperm DNA fragmentation has been examined in patients with low reproductive function. The increase of DNA fragmentation level correlates with the decrease of the blastocyst formation rates $(p<0.05)$. The significant negative relationship between sperm DNA fragmentation and the male age is proved $(\mathrm{p}<0.05)$. The age of 35 years old could be discussed as clinically critical male age for the process of chromatin compaction during the process of spermatogenesis.
\end{abstract}

Keywords: sperm DNA fragmentation, blastocyst formation rates, IVF

\section{Introduction}

\subsection{Sperm DNA Fragmentation as a Male Infertility Factor}

Recently high attention in the reproductive medicine is paid to the paternal genome failures. Assisted reproductive techniques (ART) such as conventional in vitro fertilization (IVF), and especially intracytoplasmic sperm injection (ICSI), allow couples whose sperm characteristics are impaired to obtain a pregnancy, whereas a few years ago, these couples would have had to use sperm donation in order to obtain their child. One can nevertheless wonder about the capacity of poor quality sperm samples to generate embryos having normal capacities of development. Among the factors involved in the failure of obtaining embryos and/or pregnancies, the impaired sperm genome is frequently incriminated (Ahmadi, 1999). Sperm DNA fragmentation is rather new discussible reason of male infertility. There are contradictory data about the possible influence of sperm DNA fragmentation on the sperm fertilization ability and the process of embryo development, particularly on the process of the blastocyst formation (Agarwal, 2003; Findikli, 2004; Borini, 2006). There are data about the correlation of the sperm DNA fragmentation level and high percentage of the spontaneous miscarriages for patients included in the IVF treatment (Benchaib, 2003; Seli, 2005; Oleszczuk, 2011). Sperm DNA fragmentation consists of single and doublestranded DNA breaks, frequently occurring in semen of subfertile patients (Lopes et al., 1998; Irvine et al., 2000; Muratori et al., 2000). Despite the origin and the mechanisms responsible for such genomic anomaly are not yet clarified, it has been proposed that sperm DNA fragmentation could be a good parameter to predict the male fertility status as an alternative or in addition to poorly predictive standard parameters presently determined in routine semen analysis (Lewis, 2007; Erenpreiss et al., 2006). Spermatogenesis is a complicated process that includes spermatozoa development and maturation. It depends on such factors as genetics, hormonal statement, environmental conditions etc. Spermatogenesis failures could lead to the formation of aneuploid sperm or sperm with the DNA damage (Cayli, 2004; Tesarik, 2002).

\subsection{The Etiology of Chromatin Compactization Failures}

The level of sperm DNA fragmentation reflects the integrity of genetic material of the gamete. This parameter is important since DNA lesions of many types induce mutations commonly observed in mutated oncogenes and tumour suppressor genes (Marnett, 2000). The possible reason of sperm DNA fragmentation are changing of chromatin structure during the process of spermatogenesis and apoptosis (Brugnon, 2006; Schlegel, 2005; Calle, 2008). Defects of the process of spermatozoa maturation should also be discussed. In average about $20 \%$ of spermatozoa in ejaculate could be found as apoptotic in men with different deviations in the semen analysis 
(Mehdi, 2003; Muratori, 2008). It is also found out that the sperm DNA fragmentation level is statistically higher for patients with spermatogenesis failures comparing with men with normal semen parameters (Speyer, 2012). On the next side there are data that DNA fragmentation level has no correlation with such semen parameters as motility, concentration or sperm morphology (Luke, 2010). There is still discussible question about the dependence of sperm DNA fragmentation level on the male age (Bronet, 2012). Results of studies aimed to establish whether the amount of sperm DNA fragmentation could predict the outcome of Assisted Reproduction Techniques (ARTs) are conflicting.

\subsection{The Research Design}

The aim of the presence work was to investigate the correlation for sperm DNA fragmentation level on the male age and to examine if there is any dependence in the process of the early embryo development on the sperm DNA fragmentation in patients with low reproductive function during the infertility treatment using the methods of ART. Taking into account that the most important criteria of the normal embryo development is the blastocyst formation, the affect on sperm DNA fragmentation level on the blastocyst formation rates were examined for infertile patients during the infertility treatment using the IVF procedure including the manipulation of ICSI. It was also very important to compare sperm DNA fragmentation level in the group of infertile patients and in men with normal reproductive function.

\section{Method}

\subsection{Sperm DNA Fragmentation Level Examination}

Sperm DNA fragmentation level was examined using the method of the sperm chromatin dispersion (SCD) (HaloSperm, Halotech, Spain). The method is based on the chromatin dispersion around the spermatozoa nuclei that allows finding the spermatozoa with fragmented DNA. The SCD test is based on the principle that sperm with fragmented DNA fail to produce the characteristic halo of dispersed DNA loops that is observed in sperm with non-fragmented DNA, following acid denaturation and removal of nuclear proteins. The SCD test is a simple, accurate, highly reproducible, and inexpensive method for the analysis of sperm DNA fragmentation in semen and processed sperm. It could potentially be used as a routine test for the screening of sperm DNA fragmentation in the andrology laboratory (Fernández, 2003). The examination was carried out using the fluorescent microscope Nikon Eclipse 80i. The obtained photos were documented with the cytogenetic program Lucia FISH (LIM, Czech Republic). Normally the sperm DNA fragmentation level should not be higher then $20.0 \%$.

\subsection{Participants Characteristics}

During the investigation the group consisted of 33 infertile patients with the male low reproductive function were formatted. The middle male age in the group was $38.0 \pm 5.7$ years old. The IVF procedure and the examination of the sperm DNA fragmentation level were carried out for all the participants of the mentioned group. Simultaniously the control experiment with a normal group consisted of 20 fertile men was carried out to compare the value of DNA fragmentation level. The middle male age in the control group was $34.0 \pm 6.9$ years old. Basic sperm parameters (concentration, motility and morphology) showed a high variability among individual patients, ranging between normal values and severe oligoasthenoteratozoospermia. Blastocyst formation rates were variable for the patients (Table 1). 
Table 1. Basic sperm parameters of examined group of infertile patients

\begin{tabular}{|c|c|c|c|c|c|}
\hline \multirow{2}{*}{ Patient } & \multicolumn{3}{|c|}{ Basic sperm parameters } & \multirow{2}{*}{$\begin{array}{c}\text { Sperm DNA } \\
\text { fragmentation, \% }\end{array}$} & \multirow{2}{*}{$\mathrm{BFR}, \%$} \\
\hline & Concentration $\left(\times 10^{6} / \mathrm{ml}\right)$ & Motility, \% & Normal forms, $\%$ & & \\
\hline 1 & 15 & 52 & 22 & 38.0 & 18.1 \\
\hline 2 & 34 & 26 & 31 & 3.0 & 12.5 \\
\hline 3 & 23 & 17 & 12 & 14.5 & 56.2 \\
\hline 4 & 54 & 70 & 37 & 27.5 & 0 \\
\hline 5 & 72 & 31 & 41 & 14.5 & 69.5 \\
\hline 6 & 12 & 34 & 39 & 3.8 & 50.0 \\
\hline 7 & 43 & 63 & 19 & 5.2 & 100.0 \\
\hline 8 & 7 & 13 & 15 & 20.0 & 0 \\
\hline 9 & 32 & 49 & 34 & 10.0 & 50.0 \\
\hline 10 & 8 & 35 & 21 & 33.4 & 62.5 \\
\hline 11 & 19 & 41 & 36 & 11.7 & 25.0 \\
\hline 12 & 21 & 15 & 45 & 13.2 & 78.2 \\
\hline 13 & 59 & 48 & 42 & 22.3 & 42.1 \\
\hline 14 & 37 & 52 & 39 & 42.2 & 44.4 \\
\hline 15 & 29 & 24 & 17 & 12.3 & 33.3 \\
\hline 16 & 3 & 23 & 5 & 10.5 & 47.1 \\
\hline 17 & 51 & 63 & 39 & 21.3 & 33.3 \\
\hline 18 & 26 & 17 & 14 & 61.5 & 14.3 \\
\hline 19 & 38 & 46 & 34 & 18.3 & 54.5 \\
\hline 20 & 6 & 10 & 11 & 37.5 & 14.2 \\
\hline 21 & 42 & 23 & 13 & 12.4 & 77.8 \\
\hline 22 & 40 & 39 & 25 & 9.8 & 37.5 \\
\hline 23 & 74 & 57 & 57 & 12.0 & 61.5 \\
\hline 24 & 67 & 68 & 54 & 2.0 & 80.0 \\
\hline 25 & 31 & 20 & 35 & 3.5 & 58.3 \\
\hline 26 & 18 & 23 & 13 & 60.0 & 20.0 \\
\hline 27 & 4 & 16 & 10 & 5.5 & 60.0 \\
\hline 28 & 22 & 46 & 24 & 1.5 & 61.5 \\
\hline 29 & 65 & 58 & 51 & 7.5 & 28.5 \\
\hline 30 & 11 & 29 & 9 & 14.5 & 50.0 \\
\hline 31 & 9 & 14 & 35 & 5.2 & 50.0 \\
\hline 32 & 20 & 36 & 21 & 46.7 & 38.4 \\
\hline 33 & 38 & 48 & 18 & 38.0 & 55.5 \\
\hline
\end{tabular}

\subsection{IVF Procedure}

During the IVF programs the protocols with a-GnRH (antagonist-Gonadotropin Releasing Hormone) were used for controlled ovary stimulation for oocytes retrieval. Ovary stimulation took not less then 10 days in every case. In the day of the transvaginal puncture the size of follicles achieved $18 \mathrm{~mm}$. To maintain the luteal phase the progesterone consisted medicines were used. Oocyte retrieval was carried out under general anaesthesia by a vaginal ultrasonography-guided aspiration. At 16-18 h after insemination or microinjection, as previously 
described (Borini et al., 2004a, 2004b), oocytes were assessed for two PN presence.The fertilization of oocytes was carried out using the procedure of ICSI taking into account the male factor of infertility. ICSI manipulation was done on the inverted microscope Nikon Eclise TI-u with the Eppendorf micromanipulators. Spermatozoa were immobilezed using the laser system OCTAX (MTG, Germany). The obtained oocyted and embryos were cultured in the Universal IVF Medium and ISM-1 Medium (Medicult) during the first three days and in the Blast Assist (Medicult) till the fifth day of culture. The gametes and embryos were cultured in temperature $36.8{ }^{\circ} \mathrm{C}-$ $37.1{ }^{\circ} \mathrm{C}$ and in $5.5 \%-5.8 \% \mathrm{CO}_{2}$ level.

\subsection{Statistics}

The obtained data for abnormal distribution were statistically checked using nonparametric methods of statistic analysis. The correlation was examined by the method of analysis with the Spearman coefficient. Calculation was done using the program module Statistica-6.

\section{Results}

The positive correlation between the sperm DNA fragmentation level and male age was proved for the examined group. Total Spearman coefficient is $0.35(\mathrm{p}<0.05)$. The critical male age for the sperm DNA fragmentation level growth is 35 years old. Spearman coefficient for patients elder then 35 years old is $0.45(\mathrm{p}<0.05)$. There is no any correlation for DNA fragmentation and male age in the group of patients younger then 35 years old. Spearman coefficient for the group of patients younger then 35 years old is $-0.04(p>0.05)$. The obtained results are mentioned in Table 2.

Table 2. Correlation between the sperm DNA fragmentation level and male age

\begin{tabular}{ccccccc}
\hline Age group & $\mathrm{N}$ & Age, years & DNA fragmentation, $\%$ & $\mathrm{r}_{\mathrm{s}}$ & $\mathrm{r}_{\text {critical }}$ & $\mathrm{p}$ \\
\hline$\leq 35$ years & 11 & $30.7 \pm 2.7$ & $13.5 \pm 6.6$ & -0.04 & 0.58 & $\mathrm{p}>0.05$ \\
$>35$ years & 22 & $41.6 \pm 4.4$ & $21.2 \pm 15.0$ & 0.45 & 0.43 & $\mathrm{p}<0.05$ \\
Total group & 33 & $38.0 \pm 5.7$ & $18.6 \pm 12.5$ & 0.35 & 0.34 & $\mathrm{p}<0.05$ \\
\hline
\end{tabular}

The significant negative correlation between the semen DNA fragmentation level and blastocyst formation rates is proved. However, the DNA fragmentation less then 5.0\% did not impair the blastocysts formation rates. The critical DNA fragmentation level for blastocysts formation rates is $5.0 \%$. The Spearmen coefficient for the group of patients with the DNA fragmentation level higher then $5.0 \%$ is $-0.44(\mathrm{p}<0.05)$. The Spearmen coefficient for the total examined group is $-0.41(\mathrm{p}<0.05)$. The obtained results are mentioned in Table 3 .

Table 3. Correlation between the semen DNA fragmentation level and blastocyst formation rates

\begin{tabular}{ccccccc}
\hline Critical DNA fragmentation level & $\mathrm{N}$ & DNA fragmentation, $\%$ & $\mathrm{BFR}, \%$ & $\mathrm{r}_{\mathrm{s}}$ & $\mathrm{r}_{\text {critical }}$ & $\mathrm{p}$ \\
\hline$>5.0 \%$ & 28 & $21.4 \pm 12.6$ & $43.2 \pm 18.6$ & -0.44 & 0.38 & $\mathrm{p}<0.05$ \\
$<5.0 \%$ & 5 & $2.8 \pm 0.8$ & $52.5 \pm 17.0$ & -0.60 & 0.94 & $\mathrm{p}>0.05$ \\
Total group & 33 & $18.6 \pm 12.5$ & $44.9 \pm 18.9$ & -0.41 & 0.34 & $\mathrm{p}<0.05$ \\
\hline
\end{tabular}

Photo of spermatozoa with the fragmented DNA and with normal compactization of chromatin is present on Figure 1. 


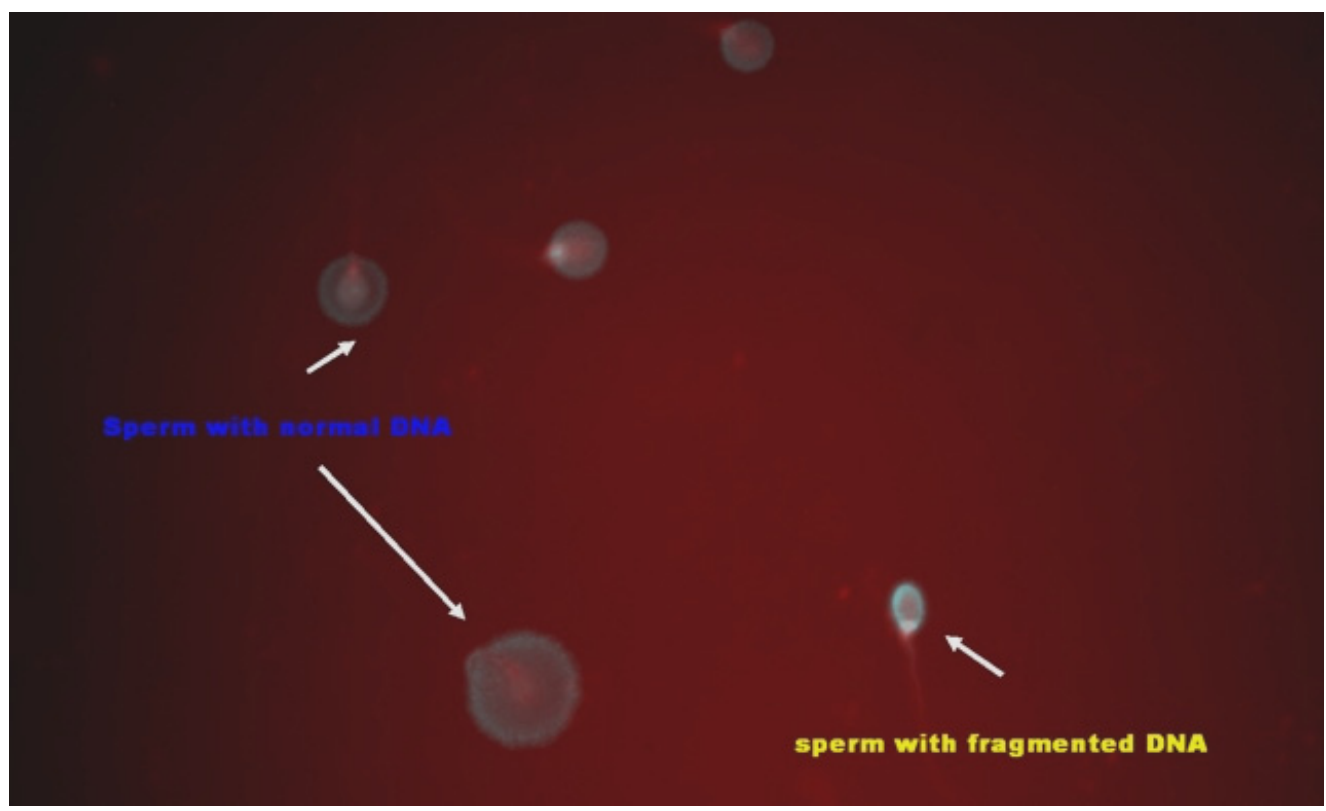

Figure 1. Sperm DNA fragmentation by the method of SCD

The average semen DNA fragmentation level in the control group of fertile men was $5.48 \pm 2.03$. The level of DNA fragmentation level was significantaly higher in infertile patients comparing with the control $(\mathrm{p}<0.05)$. Such fact could prove the influence of the sperm chromatin compactization failures on the semen parameters and male reproductive function. Further investigations should be performed.

\section{Discussion}

In studies investigating the impact of sperm DNA fragmentation on reproduction, the prevailing idea is that sperm with damaged DNA, even if retaining the ability to fertilize the oocyte (Ahmadi, 1999), affect the subsequent steps resulting in increased failure of embryo development and miscarriage (Agarwal, 2004; Lewis, 2005; $\mathrm{Li}, 2006$ ). However, data on the relationship between DNA damage and ART outcome are very conflicting (O'Brien, 2005; Li, 2006). The obtained data confirmed that DNA fragmentation could be one of the male infertility factor that effects the embryo development. The increase of DNA fragmentation showed negative correlation with the blastocyst formation rates (BFR) $(\mathrm{p}<0.05)$. The level of sperm DNA fragmentation 5.0\% could be reported as a critical one for the process of blastocyst formation in ART (assisted reproductive techniques). Such conclusion is practically important because of an absence of the strict recommendations about normal or abnormal level of semen DNA damage levels. The discussible range of acceptable level of semen DNA fragmentation varies in diapasone $10 \%-40 \%$ in different studies (Benchaib, 2003). The studies by previous workers reported above, supported by the present study, indicate clearly that strand breaks in the sperm DNAhave little or no effect on fertilization and early embryo growth but begin to have an effect at the stage of blastocyst development, and then have a very marked effect on implantation of the embryo, but the exact clinically important DNA fragmentation level that could impair the blastocyst development is still discussible (Ahmadi, 1999; Fatehi, 2006). There was no significant effect on fertilization rate or early cleavage, but the effects on blastocyst development and implantation rate were very marked. The negative correlation between the sperm DNA fragmentation on the male age is proved $(\mathrm{p}<0.05)$. The patients' age 35 years old could be discussed as clinically critical male age for the process of chromatin compaction during the spermatogenesis. Such conclusion is clinically important, taking into account that nowadays more attention to the female age is paid and there is a little information about the age of male fertility. As both males and females decide to conceive later, the question of whether this may impact their fertility individually and as a couple becomes even more crucial. A paternal age of over 40 years at the time of conception is a frequently quoted male age threshold, however, currently there is no clearly accepted definition of advanced paternal age or even a consensus on the implications of advancing male age (Humm, 2013). Further study is also needed to determine if there is any dependence of sperm DNA damage on the basic sperm parameters. Several studies have stressed the importance of traditional sperm parameters as predictors of fertility potential (Nallella et al., 2006). Because of the evidence of correlations between sperm DNA fragmentation and clinical pregnancy and pregnancy loss rates, it would be 
practically important to find a relationship between traditional sperm evaluation parameters (concentration, motility and morphology) and pregnancy and pregnancy loss rates in IVF groups.

\section{Acknowledgements}

The clinical research was performed at Feskov Center of Human Reproduction in Kharkov, Ukraine. Authors are grateful to Mr. Gakh Andrey (Kharkov National University named after V. N. Karazin) for the support in the statictics analisis.

\section{References}

Agarwal, A., \& Said, T. M. (2003). Role of sperm chromatin abnormalities and DNA damage in male infertility. Hum. Reprod., 19(4), 331-345. http://dx.doi.org/10.1093/humupd/dmg027

Ahmadi, A., \& Soon-Chye, Ng. (1999). Fertilizing ability of DNA-damaged spermatozoa. J. Exp. Zool., 284, 696-704.

http://dx.doi.org/10.1002/(SICI)1097-010X(19991101)284:6\%3C696::AID-JEZ11\%3E3.0.CO;2-E

Benchaib, M., Braun, V., \& Lornage, J. (2003). Sperm DNA fragmentation decreases the pregnancy rate in an assisted reproductive technique. Hum. Reprod., 18(5), 1023-1028. http://dx.doi.org/10.1093/humrep/deg228

Borini A, Bonu, M. A., Coticchio, G, Bianchi, V., Cattoli, M., \& Flamigni, C. (2004b). Pregnancies and births after oocyte cryopreservation. Fertil Steril, 82(3), 601-605. http://dx.doi.org/10.1016/j.fertnstert.2004.04.025

Borini, A., Tallarini, A., Maccolini, A., Dal Prato, L., \& Flamigni, C. (2004a). Perifollicular vascularity monitoring and scoring; a clinical tool for selecting the best oocyte. Eur. J. Obstet Gynecol Reprod Biol., 115, 102-105. http://dx.doi.org/10.1016/j.ejogrb.2004.01.021

Borini, A., Tarozzi, N., Bizzaro, D., Bonu, M., Fava, L., Flamigni, C., \& Coticchio, G.. (2006). Sperm DNA fragmentation: paternal effect on early post-implantation embryo development in ART. Hum. Reprod., 21(11), 2876-2881. http://dx.doi.org/10.1093/humrep/del251

Bronet, F., Martırnez, E., Gaytarn, M., Liñarn, A., Cernuda, D., Ariza, M., ... Nogales, M. (2012). Sperm DNA fragmentation index does not correlate with the sperm or embryo aneuploidy rate in recurrent miscarriage or implantation failure patients. Hum. Reprod., 27(7), 1922-1929. http://dx.doi.org/10.1093/humrep/des148

Brugnon, F., Van Assche, E., \& Verheyen, G. (2006). Study of two markers of apoptosis and meiotic segregation in ejaculated sperm of chromosomal translocation carrier patients. Hum. Reprod., 21(3), 683-685.

Calle, J. F., Muller, A., \& Walschaerts, M. (2008). Sperm deoxyribonucleic acid fragmentation as assessed by the sperm chromatin dispersion test in assisted reproductive technology programs: results of a large prospective multicenter study. Fertility and Sterility, 19(6), 671-682.

Cayli, S., Sakkas, D., Vigue, L., Demir, R., \& Huszar, G. (2004). Cellular maturity and apoptosis in human sperm: creatin kinase, caspase-3 and Bcl_xL levels in mature and diminished maturiry sperm. Mol. Hum. Reprod., 10(5), 365-372. http://dx.doi.org/10.1093/molehr/gah050

Fatehi, A. N., Bevers, M. M., Schoevers, E., Roelen, B. A. J., Colenbrander, B., \& Gadella, B. M. (2006). DNA damage in bovine sperm does not block fertilization and early embryonic development but induces apoptosis after the first cleavages. $J$. Androl., 27, 176-188. http://dx.doi.org/10.2164/jandrol.04152

Fernández, J. L., Muriel, L, Rivero, M. T., Goyanes, V., Vazquez, R., \& Alvarez, J. G. (2003). The sperm chromatin dispersion test: a simple method for the determination of sperm DNA fragmentation. J. Androl., 24, 59-66.

Findikli, N., Kahraman, S., \& Kumtepe, Y. (2004). Assessment of DNA fragmentation and aneuploidy on poor quality human embryos. Reprod Biomed Online, 8(2), 196-206. http://dx.doi.org/10.1016/S1472-6483(10)60516-0

Henkel, R., Kierspel, E., \& Hajimohammad, M. (2003). DNA fragmentation of spermatozoa and assisted reproduction technology. Reprod Biomed Online, 4 47 http://dx.doi.org/10.1016/S1472-6483(10)61893-7

Hong Y., Guo-ning, H., Yang, G., \& De, Y. L. (2006). Relationship between human sperm-hyaluronan binding assay and fertilization rate in conventional in vitro fertilization. Hum. Reprod., 21(6), 1545-1550. http://dx.doi.org/10.1093/humrep/del008

Humm, K. C., \& Sakkas, D. (2013). Role of increased male age in IVF and egg donation: is sperm DNA 
fragmentation responsible? Fertility Sterility, 99(1), 30-6. http://dx.doi.org/10.1016/j.fertnstert.2012.11.024

Lewis, S. E., \& Aitken, R. J. (2005). DNA damage to spermatozoa has impacts on fertilization and pregnancy. Cell Tissue Res., 322, 33-41. http://dx.doi.org/10.1007/s00441-005-1097-5

Li, Z., Wang, L., Cai, J., \& Huang, H. (2006). Correlation of sperm DNA damage with IVF and ICSI outcomes: a systematic review and meta-analysis. J. Assist Reprod Genet., 23, 367-376. http://dx.doi.org/10.1007/s10815-006-9066-9

Luke, S., Gunnar, B., Michael, S., \& Deborah, L. (2010). Clinical significance of sperm DNA damage in assisted reproduction outcome. Hum. Reprod., 25(7), 1594-1608. http://dx.doi.org/10.1093/humrep/deq103

Marnett, L. J. (2000). Oxyradicals and DNA damage. Carcinogenesis, 21, 361-370. http://dx.doi.org/10.1093/carcin/21.3.361

Mehdi, B., ValeÂrie, B., Jacqueline, L., \& Samia, H. (2003). Sperm DNA fragmentation decreases the pregnancy rate in an assisted reproductive technique. Hum. Reprod., 18(5), 1023-1028. http://dx.doi.org/10.1093/humrep/deg228

Muratori, M., Marchiani, S., Tamburrino, L., Tocci, V., Failli, P., Forti, G. \& Baldi, E. (2008). Nuclear staining identifies two populations of human sperm with different DNA fragmentation extent and relationship with semen parameters. Hum. Reprod., 23(5), 1035-1043. http://dx.doi.org/10.1093/humrep/den058

Nallella, K. P., Sharm, R. K., Aziz, N., \& Agarwal, A. (2006). Significance of sperm characteristics in the evaluation of male infertility. Fertil Steril., 450 85(3), http://dx.doi.org/10.1016/j.fertnstert.2005.08.024

O’Brien, J., \& Zini, A. (2005). Sperm DNA integrity and male infertility. Urology, 65, 16-22. http://dx.doi.org/10.1016/j.urology.2004.07.015

Oehninger, S., Chaturvedi, S., \& Toner, J. (1998). Semen quality is there a paternal effect on pregnancy outcome in in-vitro fertilization/intracytoplasmic sperm injection? Hum. Reprod., 13, 2161-2164. http://dx.doi.org/10.1093/humrep/13.8.2161

Oleszczuk, K., Giwercman, A., \& Bungum, M. (2011). Intra-individual variation of the sperm chromatin structure assay DNA fragmentation index in men from infertile couples. Hum. Reprod., 26(12), 3244-3248. http://dx.doi.org/10.1093/humrep/der328

Schlegel, P. N., \& Paduch, D. A. (2005). Yet another test of sperm chromatin structure. Fertil Steril., 84(4), 854-859. http://dx.doi.org/10.1016/j.fertnstert.2005.04.050

Seli, E., \& Sakkas, D. (2005). Spermatozoal nuclear determinants of reproductive outcome: implications for ART. Hum. Reprod. Update, 11(4), 337-349. http://dx.doi.org/10.1093/humupd/dmi011

Speyer, B. E., Pizzey, A. R., Ranieri, M., Joshi, R., Delhanty, J. D. A., \& Serhal, P. (2012). Fall in implantation rates following ICSI with sperm with high DNA fragmentation. Hum. Reprod., 25(7), 1609-1618. http://dx.doi.org/10.1093/humrep/deq116

Tesarik, J., Mendoza, C., \& Greco, E. (2002). Paternal effects acting during the first cell cycle of human preimplantation development after ICSI. Hum. Reprod., 17, 184-189. http://dx.doi.org/10.1093/humrep/17.1.184

\section{Copyrights}

Copyright for this article is retained by the author(s), with first publication rights granted to the journal.

This is an open-access article distributed under the terms and conditions of the Creative Commons Attribution license (http://creativecommons.org/licenses/by/3.0/). 